\title{
Brief Survey of History of Roma people in the Great Rye Island
}

\section{Sipos (Ladislav Sipos)}

Constantine the Philosopher University in Nitra, Ministry of Interior of the

Slovak Republic. Slovakia.

\section{E-mail address:}

ladislav.sipos@ukf.sk

\section{Reprint address:}

Ladislav Sipos

Constantine the Philosopher University in Nitra

94974 Nitra

Slovakia

Source: Clinical Social Work and Health Intervention

Pages: $64-67$

\section{Reviewers:}

Gunther Dorfmeister

Vienna General Hospital, Vienna, Austria

Jirina Kafkova

Nairobi, St. Bakitha Clinic, Kenya

\section{Keywords:}

The Roma History. Roma Families. Great Rye Island.

\section{Publisher:}

International Society of Applied Preventive Medicine i-gap

CSWHI 2020; 11(4): 64 - 67; DOI: 10.22359/cswhi_11_4_09 (C) Clinical Social Work and Health Intervention

\section{Abstract:}

The main aim of this work is to represent the history of Roma people on Great Rye Island. The work deals with the historical review of these Roma minorities. It shows their historical and social background down the centuries. It scopes some important regions and analyses of family names in the designated area. The biggest part of the work is a conclusion about Roma people in the period after and before the war and how they lived during these years. This work also has some analytical information about Roma families and uses some life-related materials. The end of the work sums up the most significant steps of these people. 


\section{Introduction}

In my article I would like to write about Roma people and their connection regarding present day Slovakia. I would like to present the main historical events that had a big impact on this minority group and not least emphasize their historical background. Gypsy people did not have literacy in the early period, but we have historical sources that depict that this minority group also had history.

The main aim of this article to analyze the main characteristic features of Gypsy people and their community along with a need to deal with their contemporary social background and relations.

\section{Historical review}

The first appearance of Roma people originated in the 11 th century. During the centuries, especially the 14th century was a critical period for them because some groups of Gypsies wandered traveling to various parts of Europe. According to Ravasz (2005) this can be seen as a major pathway for that minority group. He claims that some families originated in the 16th century, but this group did not connect to Great Rye Island. A main reason why they did not travel can be seen in their development as a farming population. It included household behaviors as collecting potatoes, building works, etc.

In the 17th century the problem of this civilization was the same. Some Gypsy groups travelled to Europe, but they have been prosecuted and killed. Unfortunately other groups did not like them because of their behavior. Two places where Roma people lived were Nitra and Bratislava.

The first author who wrote about Roma people was Samuel Augustini (ab Hortis). In his monography he presented some important data: „From those Gypsies who are married the children must be taken away to be far from their parents and relatives even by force to prevent them from being in any relationship with other Gypsies. At the same time, a better education should be provided for them. In some places they have already started it and where they were unwilling to support this aim voluntarily, it was enforced by violence" (Augustini, 1995, p. 62).
According to the author, it can also be seen that they had other possibilities. The other thing that Augistini dealt with was the issue of Roma children. He stated: „They have reported from Fallendorf Village on Great Rye Island that on the 24th of last month, between 5 and 6 o clock in the morning, they took again from Pruk (in Hungarian: Dunahidas, in Slovak currently Most pri Bratislave), the older children, who as with the former ones will get an education by which they will be able to gradually doff their inborn disobedience. Among the children destined for re-education there was also a 14 years old girl who was to be taken away as a bride. In her despair or anger she was tearing her hair and her behavior was always erratic" (Augustini, 1995, p. 62).

Most of the children were raised at home in family, only few of them were taken to farmer foster parents. Only two boys from Dolne Devicany (today a part of Devicany and Dunajska Streda) and Horné Saliby attended school.

Adult Roma people worked in an agricultural area during winter and they were also making some music during summertime. Many of them were smiths, harvestmen, pickers and thrashers. Most of the families lived in Velke Ulany and 13 families in Samorin. The most common family names were: Sarkozi, Mezei, Sipos, Rigo, Ujvari, Danis, Buga and Mundi (Horvathova, 1964).

The first data of Gypsies living in Nove Zamky came from the 18th century. During this period gypsies were divided into two groups: first were the new urban serfs and the other was the upper class. It included names such as Munka, Cirok, Anyalay, Balogh, Sultsek and Dome.

Roma people are connected to the Roman Catholic religion. Gypsies had a national local language, but they also spoke Hungarian. In the region of Nitra and Bratislava they also spoke the Slovak language. In Nitra $17.7 \%$, in Bratislava $22.6 \%$, in Ostrihom $59.3 \%$ and in Komarno $70.9 \%$ spoke the Romani language. These data refer to the major language assimilation of Roma people living in southern Slovakia during the 19 th century.

Another important event in Roma history was the census by the Minister of Interior on March 15, 1924. According to the Slovak National 
Archive we can find censuses in Dunajska Streda, in Galanta, in Samorin and in Komarno.

Among the 121 Gypsy family names common ones in these geographical territories were: Danis, Farkas, Koavacs/Kovac, Kurucz/Kuruc, Olah, Rigo, Sarkozi and Stojka. (Mann, 1998).

The biggest territory where they lived was the area of Dunajska Streda. According to the four biggest territories we can find some family names that were particular in these areas.

Dunajska Streda disctrict: Abraham, Banyak, Bertok, Bottlo, Burdy, Danis, Dani, Horvath, Kardos, Katona, Kurucz, Lakatos, Levai, Meszaros, Mezzei, Piroska, Rigo, Sarkozi, Sipos, Stojka, Vezpremi, Vontzemü.

Galanta disctirct: Banyak, Bartos, Bihari, Bitto, Bottlo, Farkas, Herak, Horvath, Janoska, Kardos, Karvay, Kmeto, Kok, Kovacs, Kuki, Kurucz, Lakatos, Meszaros, Mezzei, Olah, Patkolo, Rigo, Salay, Sarkozi, Sipos, Vizvary, Voros

Komarno district: Bertok, Dome, Farkas, $\mathrm{Ka}$ tona, Kovacs, Kurucz, Lakatos, Levai, Meszaros, Mezzei, Piroska, Sarkozi, Stojka, Vezpremi

Other districts: Bitto, Bujko, Burdy, Dome, Farkas, Horvath, Karvay, Kovacs, Kulina, Kuruc, Kurthy, Lakatos, Mezzei, Olah, Patkolo, Sarkozy, Stojka, Vezpremi

There were also some family names that were typical in other regions. Mezei, Rigo and Sarkozi the most widespread ones and the family name Buga was particular in Dunajska Streda, Bundi was found in Tomasov and Stvrtok na Ostrove, and the name Ujvari in Malinovo and Maly Mager (Mann, 1998).

\section{Gypsies in the Great Rye Island during the Slovak State (1939-1945)}

One of the most tragic events in the history of Roma people was their prosecution during World War II. The situation in Slovakia was not very good for them because they had to deal with the same problems as other minorities like the Hungarians. During that period C. Necas was the only person who wrote one monography about that time and the social and economic background of Gypsy people. He described the situation that during the war there were anti-Roma rules and Nazi Germany had also some cruel activities against these minorities.

They were taken to relocation camps situated in Komarno. After that, the German nation took them into concentration camps, mainly to Dachau. Many of Roma people that were originated from Great Rye Island were transported from Hurbanovo. On March 30, 1945 the German army stopped there and during the evening 53 Gypsy adults and 7 children were killed. It was a taboo topic for many years. From that period we have just a very short description because many of the survivors and local people did not want to reveal the situation therefore we did not have many sources (Necas, 1994).

\section{The Gypsies and Southern Slovakia after 1989}

The population of Gypsy origin were censused by the state administration authorities without their knowledge. The last such census reflects the state as of December 31, 1989, according to which in the four districts of Great Rye Island 21,988 Roma people lived in total, making up $4.6 \%$ of the total population. In the individual districts the number and rate of Roma population developed as follows: Dunajska Streda 5,558 (5.1\%), Galanta 7,365 (5.1\%), Komarno 3,880 (3.5\%), Nove Zamky 5,185 (3,4 $\%)$. The Gypsies of Great Rye Island usually belong to the group of Roma settled down a long time ago. With the subgroup of Hungarian Roma (Rumungro), in the northern part of the region we can also find Slovak Gypsies. The border between the two groups has been undefined so far, and probably developed according to the number of ethnically dominant population.

In the census held in March 1991, after a period of 60 years, Roma people for the first time had the chance to freely ethnically identify themselves. In Slovakia 80,627 persons identified themselves as being of Roma ethnicity. This data was less than one-third the data according to the official census held in 1989. In general, it can be stated that Gypsies follow the ethnicity of the majority population of their direct environment. The comparison of data of the population census on 1991 and the data of last population conscription by the so called national councils in the Communist era (1989) shows that in the districts of southern Slovakia with major ethnic Hungarian population fewer probably Roma people identified themselves as being actually of Roma ethnicity than in the regions with major Slovak majority population. Thus for example in the Dunajska Streda district 686 persons identi- 
fied themselves as of Roma ethnicity, which is $12.3 \%$ of the assumed Roma population; in the other districts these data were as follows: Galanta 782 (10.6\%), Komarno 925 (23.8\%), Nove Zamky 764 (14.7\%).

The above mentioned census of Gypsy population in 1893 also showed that Roma people living in southern Slovakia have assimilated in their language to the local Hungarian population. It can be assumed that the Roma population considered Hungarian culture as a role model, which they had tried to adopt. In this process another important fact played a role, that since the 19th century the performers of popular Hungarian melodies have been mainly Gypsy musicians, which contributed to the decrease of ethnicalcultural differences (Mann, 1998). Roma people may consider the forcing of belonging to Roma ethnicity as a manifestation of segregation. What has been also revealed is an incident in Zlate Klasy in 1995. In September, teachers distributed primers in Roma language to the pupils in order to diminish the language handicap of the children. The next day the outraged parents came to the school and returned the textbooks saying that their children are the same as the others. This incident reinforces our assumption that for Roma people the language of the majority is more important than their own mother tongue.

Gypsies living on Great Rye Island have been known as excellent musicians. As an example of this we can mention that in 1854 in Nove Zamky there lived 43 families having 218 members out of which 22 were musicians. In the late 19 century, here lived the famous Lajos Kolompar Komlosi who with his band also performed in Budapest, Vienna, London, Berlin and Dresden. In the interwar period the talented Roma musicians performed not only in Bratislava but also in other bands playing in cafés and spas in other cities (among these the most famous musician families were: Balogh, Banyak, Bertok, Bihari, Bitto, Buga, Danis, Farkas, Levay, Mozsi, Olah, Piroska, Rigo, Szendrey, Sarkozi). Smithery music was widespread among the Gypsies even after World War II mainly in Podunajske Biskupice. The 10 smitheries performing artistic blackwork mainly for foreign clients operating in Dunajska Luzna represents an especially outstanding level of these smithery workshops.

\section{References:}

1. AUGUSTINI H S (1995) Gypsies in the former Kingdom of Hungarian 1775. Bratislava: Studio DD p. 203. ISBN 80-967263-2-3.

2. HORVATHOVA E (1964) The Gypsies in Slovakia. Bratislava: Slovak Academy of Sciences. p. 396.

3. MANN A B (1998) The Problem of Identity of Romany People. In: Identity of Ethnic Groups and Communities:the Results of Slovak Ethnological Research. (ed. G. Kilianova and E. Riecanska), Bratislava: Institute of Ethnology of Slovak Academy of Sciences. p. 64. ISBN 80-88908-03-5.

4. NECAS C (1994) The Czechoslovak Roma in years 1938 - 1945. Vol. 1. Brno: Masaryk University. p. 95-99. ISBN 8021009454.

5. RAVASZ J (2005) Identity of Roma living in the Great Rye Island. Dunajska Streda: Association of Roma writers and artists in Slovakia. p. 30. ISBN 80-969388-6-X. 